\title{
Effects of Fertilization Rate and Water Availability on Peanut Growth and Yield in Senegal (West Africa)
}

\author{
Babacar Faye $^{1,3}$, Heidi Webber ${ }^{2}$, Thomas Gaiser ${ }^{2}$, Mbaye Diop ${ }^{3}$, Joshua D. Owusu-Sekyere ${ }^{4} \&$ Jesse B. Naab $^{5}$ \\ ${ }^{1}$ West African Science Service Center on Climate Change and Adapted Land Use (WASCAL), School of \\ Agriculture, University of Cape Coast, Ghana \\ ${ }^{2}$ Crop Science Group, Institute of Crop Science and Resource Conservation (INRES), University of Bonn, \\ Katzenburgweg 5, D-53115 Bonn, Germany \\ ${ }^{3}$ Institut Sénégalais de Recherches Agricoles (ISRA), Bambey BP: 211, Senegal \\ ${ }^{4}$ Department of Agricultural Engineering, School of Agriculture, University of Cape Coast, Cape Coast, Ghana \\ ${ }^{5}$ West African Science Service Center on Climate Change and Adapted Land Use (WASCAL) Competence \\ Center, Ouagadougou, Burkina Faso
}

Correspondence: Babacar Faye, School of Agriculture, University of Cape Coast, P. O. Box 5007, Ghana; Institut Sénégalais de Recherches Agricoles (ISRA), Bambey BP: 211, Senegal. Tel: 22-17-7520-8222. E-mail: bbcrfy@yahoo.fr

Received: September 29, 2016 Accepted: October 18, 2016 Online Published: November 30, 2016

doi:10.5539/jsd.v9n6p111

URL: http://dx.doi.org/10.5539/jsd.v9n6p111

\begin{abstract}
The effects of fertilization rate and water availability on peanut growth and yield of two cultivars were investigated in a series of field experiments at Bambey, Nioro and Sinthiou Malem in Senegal. Both rainy and dry season experiments were conducted over two years between 2014 and 2015, for a total of seven experiments. The first set of four experiments were to evaluate fertilizer application rate on peanut production. One experiment was conducted in the dry season 2014 in Nioro with four levels of fertilizer and one experiment in the rainy season 2014 in each of Bambey, Nioro and Sinthiou Malem with six levels of fertilizer in a RCBD with four replications both. The second set of experiments were to evaluate the effect of different water regimes on peanut production. Experiments were conducted in the dry season of 2014 and 2015 in Bambey and in Nioro 2015. The experimental design was a split plot design with four replications and three levels of water, namely, E, $\mathrm{S} 1$ and S2. The effects of fertilization rate on peanut in three different sites were not significantly different between fertilizer levels. However, irrigation treatments were significantly different in all sites during the two years. Under water stressed conditions, the seed yield was more affected than the biomass yield. Seed yield decreased by $33 \%$ when stress occurred at flowering period and by $50 \%$ when stress occurred during seed filling. The most sensitive period for yield declined was observed during the period of maturation followed to the flowering stage. The interaction between irrigation and fertilizer was not signification in both Bambey and Nioro sites of field experiments. Such experiments should be conducted in field based conditions where occur limited soil nutrients to test higher dose of NPK.
\end{abstract}

Keywords: water stress, irrigation, fertilizer, peanut, Senegal

\section{Introduction}

Peanut (Arachis hypogaea L.) is one of the world's most important legumes, grown primarily for its high quality edible oil and protein (Kambiranda et al., 2011). It is cultivated in over 100 nations around the world with the main producers being China and India, with more than $60 \%$ of total production while Africa has $25 \%$ of the production (Noba et al., 2014). Most of the production is domestically used and only small proportion of the world production is devoted to imports and exports, therefore, the world trade market can be considered as a residual market (Revoredo and Fletcher, 2002). The proportion of peanut used for food purposes increases compare to the proportion used to produce vegetable oil. Africa is the more affected for this changes due to the lower quality of the production which contained an important level of aflatoxin (Bankole and Adebanjo, 2004; Martin et al., 1999). The contamination of peanut to aflatoxin in Africa is also due to increase drought (Kambiranda et al., 2011). West African countries are the main producer of peanut in Africa where Nigeria and 
Senegal occupied the first place followed by Mali and Niger (Singh et al., 2013).

Peanut is the country's primary industrial crop and constitutes the principal source of agricultural incomes for the majority of farmers in Senegal (Pélissier, 1966).

However, since the 1990s, peanut value chains has entered a deep crisis and various agricultural policies have yet to succeed in boosting the sector (Freud. et al., 1997).

A reduction of $25.8 \%$ of the production is observed when we compare the mean from 1972 to 1975 with the mean from 1996 to 2000 (Revoredo and Fletcher, 2002).

The decline in peanut production Senegal is mainly due to climate variability and lack of input supply and specially low quality of seeds (Foncéka, 2010). Other factors that have led to the decline of production are soil degradation, reduction of cultivated area, bad agriculture practices, lack of and poor maintenance of agricultural machinery and difficult access to credit (Gaye, 2013; Montfort, 2005).

The effect of drought stress on peanut has been an important subject investigation and was used to support development of adapted varieties (Gautreau, 1982). It depends of the duration of the drought stress, on the stage of peanut growth and the intensity of the stress. While the application of fertilizer on peanut result in enhanced normally the yield up to certain level but can have negative effect on yield if the application is not reasoned mainly for over applications and the time of applications.

The effects of drought stress is known to be more drastic on peanut when occurred during the reproductive phases than the vegetative phases (Hemalatha et al., 2013; Jongrungklang et al., 2013). Drought stress in pre-flowering has no effect in peanut yield. While the greatest reduction in kernel yield due to drought stress occurred during the seed filling phase whereas an increase of pod yield by at least $13 \%$ occurred when drought stress is imposed during the early phase (Rao et al., 1985; Stirling et al., 1989). Above ground biomass is affected negatively whenever the drought stress imposed, however, the leaf area of index of peanut stressed during the reproductive phase was lower than the leaf area index of peanut during the vegetative phase (Nautiyal et al., 2002). Drought at the end of the season affected more pod yield than number of mature pods which is most sensitive to mid season drought (Kenchanagoudar et al., 2002).

The mechanisms of physiological adaptation to drought were also investigated on peanut in Senegal which aim to select adapted peanut varieties (Annerose, 1988; Clavel et al., 2007; Clavel et al., 2005) and to identify the sensitivity of peanut growth to drought (Annerose, 1985; Annerose, 1990).

A part drought and high temperature stress, nutrient deficiencies mainly $\mathrm{N}, \mathrm{P}$ and $\mathrm{K}$ caused significant yield losses in semiarid regions but they are lower than for most other crops with a general requirement of $20 \mathrm{~kg} \mathrm{~N} / \mathrm{ha}$, 50-80kg P/ha, and 30-40kg K/ha (Prasad et al., 2010). Phosphorus is the most important nutrient for peanut in semiarid zone (Naab et al., 2015). In most case in Africa, peanut is grown in soil with phosphorus deficiency which is a limited yield factors under on-farm conditions (Naab et al., 2009; Ogeh and Oyibo, 2015).

No studies were identified that were conducted in Senegal to assess the effect of drought stress in the different stage of peanut growth associated to the response of different fertilizers application.

The aim of this study is to assess the effects of fertilizer response and water stress on peanut development, growth and yield in Senegal. To achieve this aim, field experiments were conducted in three different part in Senegal to (i) to evaluate the most sensitive period of peanut to water stress on yield reduction and (ii) to determine the effect of mineral fertilizer rate on peanut in Senegal.

\section{Materials and Methods}

\subsection{Study Sites}

The study was conducted in Senegal in three different agro-climatic zones. All trials are conducted at the Senegalese Institute of Agricultural Research (ISRA) sites (Figure 1). The first site was Bambey research station located at, $14^{\circ} 42^{\prime} \mathrm{N}$ and $16^{\circ} 29^{\prime} \mathrm{W}$. The second site was Nioro research station located at $13^{\circ} 45^{\prime} \mathrm{N}$ and $15^{\circ} 46^{\prime} \mathrm{N}$. The third site was the Sinthiou Malem research station located at $13^{\circ} 49^{\prime} \mathrm{N}$ and $13^{\circ} 54^{\prime} \mathrm{W}$. Bambey and Nioro belong to the Senegal's Peanut Basin zone which constitutes the country's most important peanut production area. 


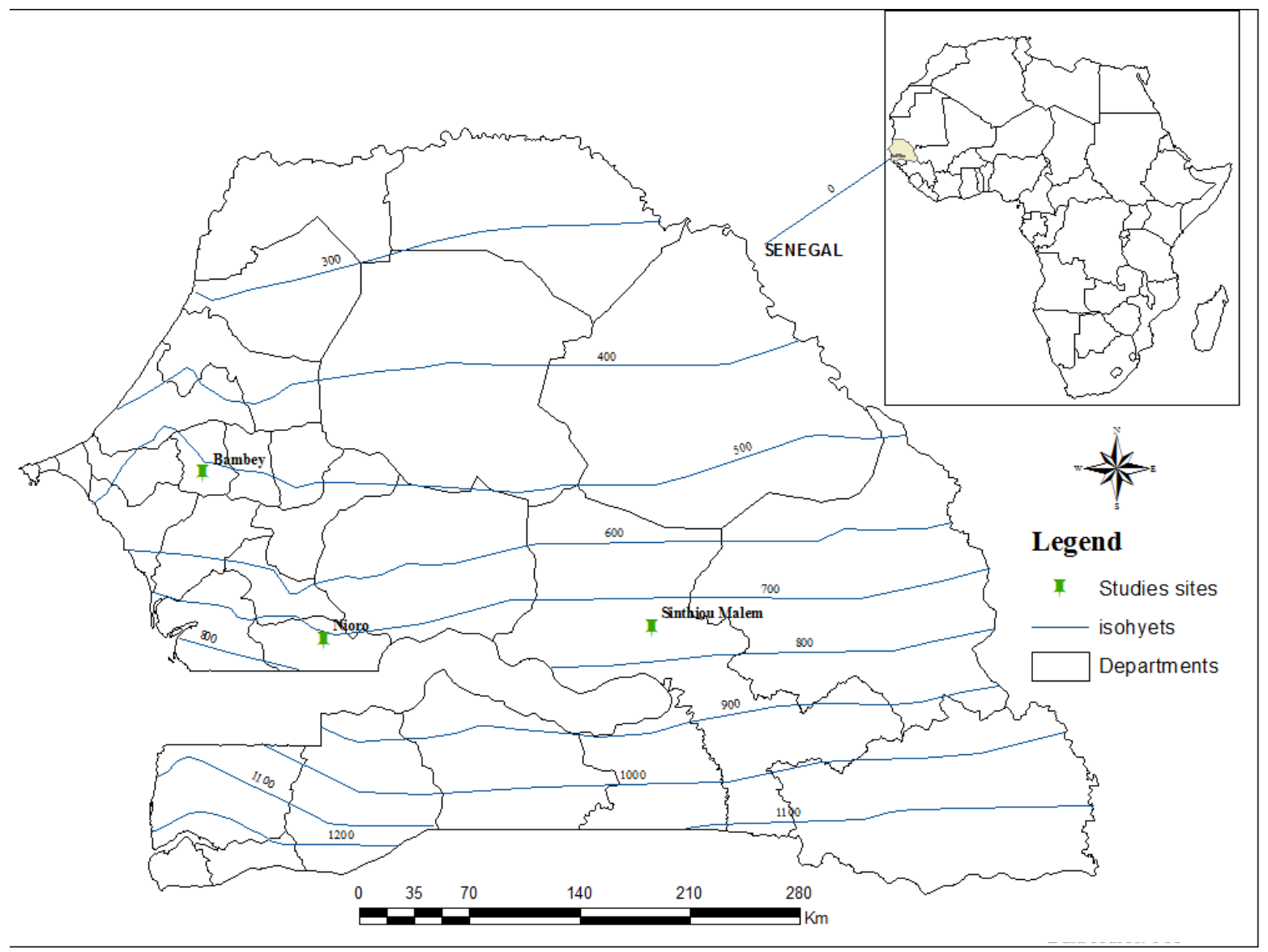

Figure 1. Study Area, normal rainfall: period 1961-1990 mm

The zone is characterized by a Sudano-Sahelian climate (Bambey) to a Sudanian climate (Nioro and Sinthiou Malem) where the variation in rainfall ranges between 400 to $800 \mathrm{~mm}$ per year (Ganry and Gueye, 1992).

The rainy season is uni-modal and the rain is mostly concentrated in three to four months between June to September. The highest amount of rainfall is recorded in August (Figure 2). The minimum temperature varies between 18 to $20^{\circ} \mathrm{C}$ in December to January, while the maximum temperature varies between 40 to $42^{\circ} \mathrm{C}$ and occurs in April to May with a maximum value of $42.6^{\circ} \mathrm{C}$ in Sinthiou Malem on April, the hottest month in all sites. Maximum solar radiation occurs in April $\left(25 \mathrm{MJ} \mathrm{m}^{-2} \mathrm{day}^{-1}\right)$ and the minimum in December $\left(15 \mathrm{MJ} \mathrm{m}^{-2}\right.$ day $\left.^{-1}\right)$. The lowest mean relative humidity is observed during the dry season and varies between 25 to $30 \%$, in contrast during the rainy season it varies between 70 to $80 \%$. 

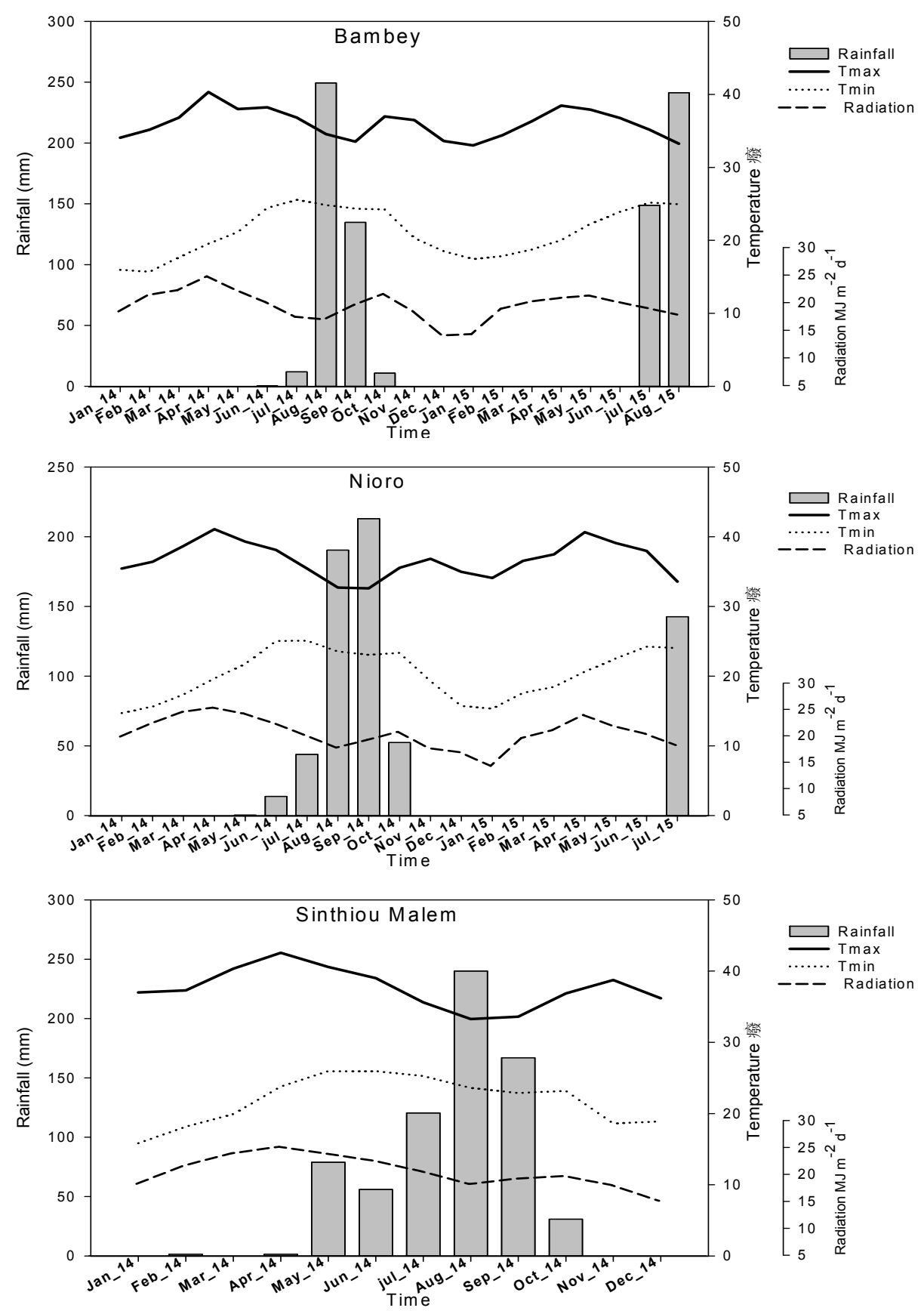

Figure 2. Seasonal cycle for climate variables during the growing season 2014 and 2015 Bambey (January 2014 to August 2015), Nioro (January 2014 to July 2015) and Sinthiou Malem (January to December 2014), with monthly rainfall (bars), monthly maximum (solid lines) and minimum (dashed lines) temperatures and monthly radiation (dotted lines)

\section{Source: CNRA Bambey and ANACIM}

There are three different types of soil in the study area depending on the average percentage of silt and clay in the top $40 \mathrm{~cm}$ layers. Tropical ferruginous soils commonly called "sol Dior" which are found mainly in Bambey $($ Clay + Silt $<12 \%)$, tropical ferruginous leached soils commonly called "sol Deck-Dior" at all sites $(12 \%<$ Clay + Silt $<15 \%$ ), and tropical ferruginous hydromorphic soils commonly called "sol Deck" found mainly in Nioro and Sinthiou Malem (Clay + Silt $>15 \%$ ). These soils are low in nitrogen content, which ranges between 0.2 and $0.3 \%$ and generally low in available phosphorus which is less than $30 \mathrm{ppm}$ (AGETIP, 1995). 


\subsection{Description of the Experimental Data}

Field experiments were conducted in Bambey, in Nioro and in Sinthiou Malem research stations of ISRA during the dry seasons 2014 and 2015 and the rainy season 2014.

A total of seven field experiments were carried out in these three sites. Two dry season field experiments in Bambey and in Nioro and one rainy season field experiment in each site (Table1). The peanut cultivars selected were Fleur 11 (V1) Spanish type and 73-33 (V2) Virginia type which are known to be early (90 days) and medium (110 days) maturity cultivars respectively. Composite fertilizer 6-20-10 was applied just after sowing as recommended by the National Agricultural Research Institute of Senegal (ISRA) for a dose of $150 \mathrm{~kg} / \mathrm{ha} . \mathrm{N}$ as total nitrogen, $\mathrm{P}$ as single superphosphate tripe $\left(\mathrm{P}_{2} \mathrm{O}_{5}\right)$ and $\mathrm{K}$ as potassium oxide $\left(\mathrm{K}_{2} \mathrm{O}\right)$ during de dry season. However, during the rainy season single doses of $\mathrm{N}$ (urea $46 \%$ ), $\mathrm{P}\left(\mathrm{DSP} 24 \% \mathrm{P}_{2} \mathrm{O}_{5}\right)$ and $\mathrm{K}\left(\mathrm{KCL}\right.$ with $\left.60 \% \mathrm{~K}_{2} \mathrm{O}\right)$ where applied in treatment T4 and T5 (Table 1). The three irrigation levels were: E, irrigation applied at field capacity on plants with no water stress; S1, irrigation applied on plants with water stress during the flowering period ( 25 days after sowing); and S2, irrigation applied on plants with water stress during seed filling (70 days after sowing). Experimental units measured $16 \mathrm{~m}^{2}(4 \mathrm{mx} 4 \mathrm{~m})$. Row spacing was $50 \mathrm{~cm}$ between rows (inter-row) and $15 \mathrm{~cm}$ in the rows (intra-row).

Before sowing each year, the field was disc-plowed to a depth of $12 \mathrm{~cm}$, harrowed and levelled. The seeding was done by hand at a depth of $4 \mathrm{~cm}$ with two seeds per seed hole. Seeds were treated with Saxal fungicide to protect them from insects and diseases. Thinning to one plant per seed hole was done after emergence at 11 days after sowing (DAS). Weed control was done by hoe and pest was controlled by chemical pesticide where attacks occurred.

Table 1. Summary of the treatments in the seven field experiments

\begin{tabular}{|c|c|c|c|c|c|c|c|}
\hline Sites & Seasons & $\begin{array}{l}\text { Irrigation } \\
\text { Levels }\end{array}$ & $\begin{array}{l}\text { Fertilizer } \\
\text { Levels }\end{array}$ & $\begin{array}{l}\text { Variety } \\
\text { Levels }\end{array}$ & Repetition & Design & $\begin{array}{l}\text { Planting } \\
\text { Month }\end{array}$ \\
\hline $\begin{array}{l}\text { Bambey } \\
\text { Nioro }\end{array}$ & $\begin{array}{l}\text { Rainy season } \\
2014\end{array}$ & No irrigation & $\begin{array}{l}\text { Six (T0, T1, T2, T3, } \\
\text { T4, T5) }\end{array}$ & $\begin{array}{l}\text { Two } \\
(\mathrm{V} 1, \mathrm{~V} 2)\end{array}$ & Four & RCBD & $\begin{array}{l}\text { August } \\
\text { July }\end{array}$ \\
\hline Sinthiou Malem & & & & & & & July \\
\hline Bambey & Dry Season & Three (E,S1,S2) & Two $(\mathrm{T} 0, \mathrm{~T} 3)$ & $\begin{array}{l}\text { Two } \\
(\mathrm{V} 1, \mathrm{~V} 2)\end{array}$ & Four & $\begin{array}{l}\text { Split } \\
\text { plot }\end{array}$ & March \\
\hline Nioro & 2014 & One $(\mathrm{E})$ & Four (T0, T1, T2, T3) & $\begin{array}{l}\text { Two } \\
(\mathrm{V} 1, \mathrm{~V} 2)\end{array}$ & Four & RCBD & March \\
\hline $\begin{array}{l}\text { Bambey } \\
\text { Nioro }\end{array}$ & $\begin{array}{l}\text { Dry Season } \\
2015\end{array}$ & Three (E,S1,S2) & Two (T0, T3) & $\begin{array}{l}\text { Two } \\
(\mathrm{V} 1, \mathrm{~V} 2)\end{array}$ & Four & $\begin{array}{l}\text { Split } \\
\text { plot }\end{array}$ & $\begin{array}{l}\text { February } \\
\text { February }\end{array}$ \\
\hline
\end{tabular}

Footnote: $\mathrm{T} 0=$ without fertilizer, $\mathrm{T} 1=$ with $33 \%$ of recommended dose, $\mathrm{T} 2=66 \%$ with recommended dose and $\mathrm{T} 3=$ recommended dose that is $150 \mathrm{kgha}^{-1}$ of 6-20-10, T4 = same level of T3 without Phosphorus and T5 = same level of $\mathrm{T} 4$ with $50 \%$ of phosphorus. $\mathrm{RCBD}=$ Randomized Complete Block Design

\subsection{Field Observations and Measurements}

Phenology observations were taken at interval of 7 days to determine parameters such as, day of emergence, day of flowering, beginning of peg, beginning of pod formation, beginning of seed and physiological maturity as described in (Boote, 1982; Meier, 2001). A given stage was considered achieved when $50 \%$ of the plants sampled had achieved the specified node number or have one or more flowers, pegs, pods, or seeds exhibiting the specified trait. A total of five plants were selected and tagged in the yield square and followed during the growing season for each plot. The observed emergence occurred on average in all the sites at 6 days after sowing . However, the date of emergence was faster during the rainy season. The early emergence occurred at five days after sowing where the quantity of rain received before sowing was more than $20 \mathrm{~mm}$, case of Sinthiou Malem and Bambey. During the dry season, emergence could be delayed up to eight days after sowing when the soil was not humid enough,. The appearance of the first leaf occurred on average two to three days after emergence. The two varieties had the same number of leaves in the main stem (Figure 3). Vegetative stage is defined as one developed node with one tetrafoliate leaf unfolded and its leaflets flat (Boote, 1982). The observed flowering date occurred on average in all sites and for both years, for Fleur 11 from 24 DAS during the 
rainy season and 30 DAS during the dry season and for 73-33 from 32 DAS during the rainy season to 36 DAS during the dry season.

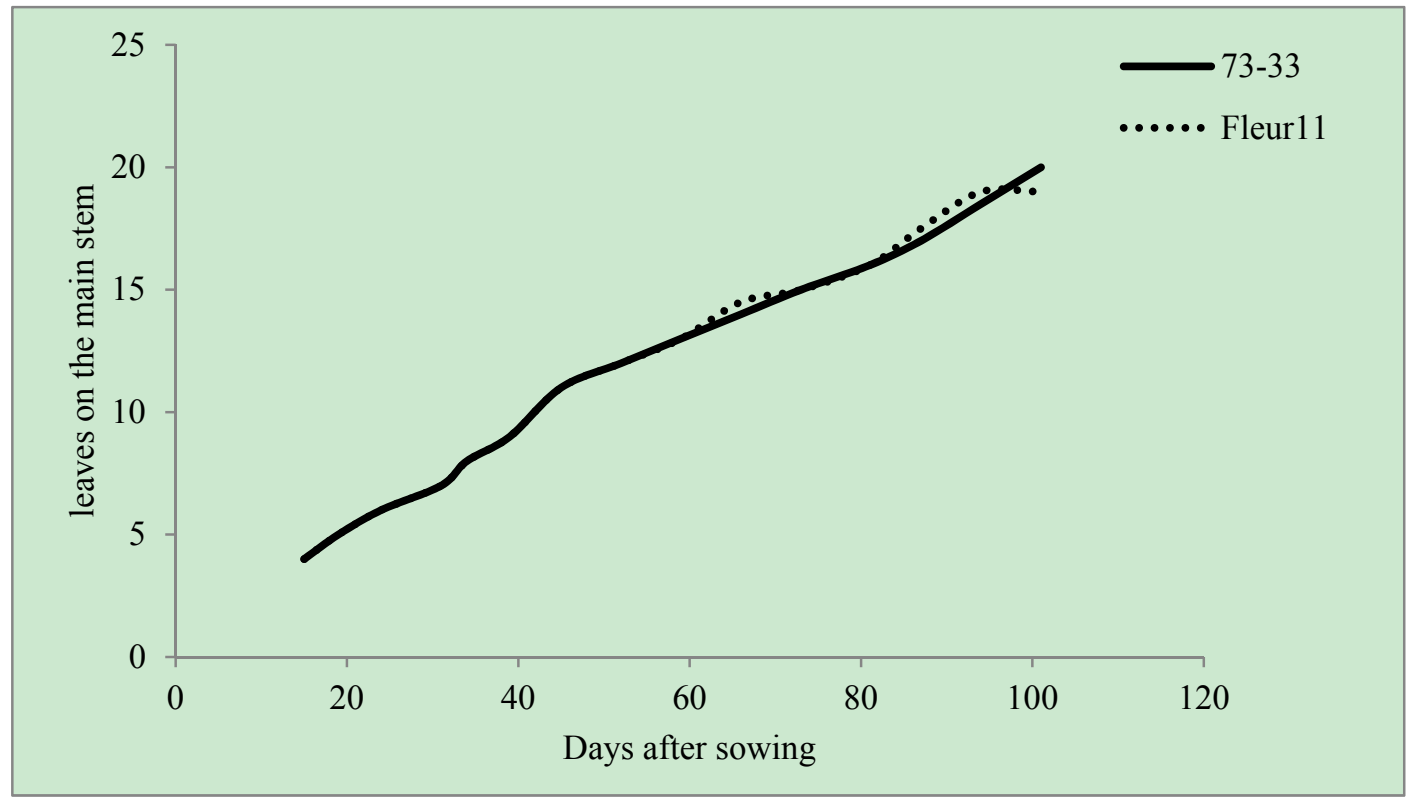

Figure 3. Number of leaves on the main stem of Fleur 11 and 73-33

Total dry matter was determined in leaves, stems and pods at different stages of the growing season on weekly basis. Final harvest was determined at maturity in each plot in an area of $3.9 \mathrm{~m}^{2}(2 \mathrm{~m} \mathrm{x} \mathrm{1.95m).} \mathrm{Time} \mathrm{series} \mathrm{of} \mathrm{leaf}$ area index (LAI-2000, 1992; Webb et al., 2008) were measured before each biomass sampling in all sites with LAI 2000 early in the morning or late in the afternoon at Bambey and Nioro or SunScan at noon at Sinthiou Malem.

Composite soil samples were collected in $10 \mathrm{~cm}$ intervals from 0 to $100 \mathrm{~cm}$ depth using an auger in all sites. Samples were air-dried, kept in polythene bags and brought to the laboratory for physical and chemical analysis in 2014 in ISRA's plant-soil laboratory and in 2015 in the National Institute of Pedology (INP).

Data analysis showed a low contain of organic carbon in Bambey both in 2014 and 2015 in the top 50cm of the soil with an average of $0.2 \%$ nitrogen content $(0.014 \%$ to $0.028 \%)$. However, phosphorus content was higher in 2014 (28ppm) compared to 2015 (2.62ppm) in which the phosphorus content was lower (Tables 2 and Table 3). The clay content was less than $5 \%$ with a depth of 1 metre which ensured a low cation exchange capacity. The percentage of sand reached $90 \%$ or more with low water holding capacity. The soil moisture content at wilting point (LL) was $14 \mathrm{~mm} / \mathrm{m}$ and the soil moisture content at field capacity (DUL) was $134.5 \mathrm{~mm} / \mathrm{m}$ that gives a maximum Agricultural Water Reserve (AWR) of $120.5 \mathrm{~mm} / \mathrm{m}$ (Sarr et al., 1999).

In Nioro, the soil was higher in organic carbon in the top soil $(0.7 \%)$ which allowed a higher cation exchange capacity, but the $\mathrm{pH}$ was more acid than Bambey. Soil clay content was less than $10 \%$. The phosphorus content was $12.91 \mathrm{ppm}$ in 2014 and $4.97 \mathrm{ppm}$ in 2015 because of the phosphorus uptake by the previous maize crop. 
Table 2. Analysis of soil physical and chemical properties at the experimental sites in 2014

\begin{tabular}{llllllllllll}
\hline location & horizon & $\mathrm{pH}$ & $\mathrm{C}$ & $\mathrm{N}$ & $\mathrm{K}$ & $\mathrm{P}$ & $\mathrm{CEC}$ & $\mathrm{A}$ & $\mathrm{L}$ & $\mathrm{S}$ & $\mathrm{bd}$ \\
\hline \multirow{6}{*}{ BAMBEY } & $0-10$ & 6.3 & 0.160 & 0.015 & 0.139 & 45.08 & 3.39 & 2.82 & 1.53 & 94.95 & 1.48 \\
& $10-20$ & 5.8 & 0.144 & 0.024 & 0.119 & 40.71 & 2.67 & 3.77 & 1.7 & 92.7 & 1.48 \\
& $20-30$ & 5.8 & 0.128 & 0.024 & 0.112 & 39.83 & 2.90 & 5.07 & 1.63 & 91.8 & 1.47 \\
& $30-40$ & 5.8 & 0.152 & 0.020 & 0.119 & 36.33 & 3.36 & 6.15 & 1.72 & 91.15 & 1.57 \\
& $50-50$ & 5.8 & 0.256 & 0.039 & 0.125 & 26.26 & 3.59 & 6.95 & 1.77 & 89.85 & 1.44 \\
& $50-60$ & 5.7 & 0.088 & 0.015 & 0.119 & 24.95 & 3.36 & 7.17 & 1.65 & 89.7 & 1.44 \\
& $70-80$ & 5.6 & 0.128 & 0.015 & 0.134 & 20.13 & 4.33 & 6.45 & 2.22 & 91.5 & 1.35 \\
& $80-90$ & 5.8 & 0.080 & 0.015 & 0.108 & 18.38 & 4.45 & 6.07 & 2.03 & 90.35 & 1.31 \\
& $90-100$ & 5.9 & 0.088 & 0.015 & 0.112 & 18.82 & 4.41 & 5.92 & 1.25 & 87.6 & 1.44 \\
\hline \multirow{6}{*}{ NIORO } & $0-10$ & 6.2 & 0.487 & 0.049 & 0.183 & 37.2 & 3.51 & 4.45 & 4.32 & 92.8 & 1.40 \\
& $10-20$ & 5.1 & 0.447 & 0.029 & 0.139 & 23.64 & 5.30 & 3.24 & 9.73 & 88.65 & 1.40 \\
& $20-30$ & 5.1 & 0.383 & 0.024 & 0.104 & 16.19 & 4.76 & 3.43 & 10.32 & 86.45 & 1.47 \\
& $30-40$ & 5.6 & 0.359 & 0.020 & 0.113 & 10.94 & 3.31 & 3.06 & 9.21 & 86.6 & 1.43 \\
& $40-50$ & 5.6 & 0.335 & 0.015 & 0.114 & 10.07 & 2.67 & 4.01 & 12.04 & 84.25 & 1.41 \\
& $50-60$ & 5.6 & 0.211 & 0.010 & 0.125 & 7.44 & 3.59 & 4.63 & 13.89 & 80.7 & 1.35 \\
& $60-70$ & 5.7 & 0.208 & 0.015 & 0.125 & 6.13 & 4.05 & 18.42 & 3.58 & 77.55 & 1.24 \\
& $70-80$ & 5.8 & 0.192 & 0.015 & 0.147 & 5.25 & 4.51 & 21.4 & 4.12 & 74 & 1.20 \\
& $80-90$ & 5.9 & 0.207 & 0.010 & 0.135 & 7 & 4.55 & 14.82 & 11.03 & 73.05 & 1.17 \\
& $90-100$ & 6 & 0.168 & 0.029 & 0.154 & 5.25 & 4.88 & 23.9 & 4.25 & 72.5 & 1.15 \\
\hline
\end{tabular}

Table 3. Analysis of soil physical and chemical properties at the experimental sites in 2015

\begin{tabular}{llllllllllll}
\hline localities & horizon & $\mathrm{pH}$ & $\mathrm{C}$ & $\mathrm{MO}$ & $\mathrm{N}$ & $\mathrm{K}$ & $\mathrm{P}$ & $\mathrm{CEC}$ & $\mathrm{A}$ & $\mathrm{L}$ & $\mathrm{S}$ \\
\hline & $0-10$ & 7.9 & 0.156 & 0.269 & 0.014 & 0.012 & 0.04 & 8 & 4 & 17.135 & 78.87 \\
& $10-20$ & 7.8 & 0.293 & 0.504 & 0.028 & 0.02 & 0.04 & 9 & 5.75 & 15.065 & 79.19 \\
& $20-30$ & 7.7 & 0.215 & 0.370 & 0.014 & 0.016 & 0.13 & 9 & 7 & 15 & 78.00 \\
& $30-40$ & 6.9 & 0.312 & 0.538 & 0.028 & 0.02 & 7.68 & 10 & 6.25 & 19.74 & 74.01 \\
BAMBEY & $40-50$ & 6.6 & 0.273 & 0.471 & 0.028 & 0.012 & 6.53 & 18 & 9.25 & 20.72 & 70.03 \\
& $50-60$ & 6.6 & 0.351 & 0.605 & 0.028 & 0.008 & 3.33 & 19 & 10.25 & 48.26 & 41.49 \\
& $60-70$ & 6.3 & 0.234 & 0.403 & 0.028 & 0.04 & 2.99 & 20 & 11 & 32.425 & 56.58 \\
& $70-80$ & 6.1 & 0.176 & 0.303 & 0.014 & 0.02 & 1.79 & 22 & 10.5 & 34.555 & 54.95 \\
& $80-90$ & 6.3 & 0.195 & 0.336 & 0.014 & 0.016 & 1.75 & 20 & 14.5 & 27.11 & 58.39 \\
& $90-100$ & 6.2 & 0.195 & 0.336 & 0.014 & 0.012 & 1.92 & 21 & 15.75 & 26.205 & 58.05 \\
\hline \multirow{5}{*}{ NIORO } & $0-10$ & 5.8 & 0.488 & 0.840 & 0.042 & 0.016 & 15 & 24 & 5.5 & 25.545 & 68.96 \\
& $10-20$ & 5.0 & 0.371 & 0.639 & 0.028 & 0.02 & 10 & 33 & 8.5 & 28.58 & 62.92 \\
& $20-30$ & 4.8 & 0.234 & 0.403 & 0.014 & 0.02 & 11 & 34 & 10.25 & 31.705 & 58.05 \\
& $30-40$ & 4.9 & 0.429 & 0.740 & 0.042 & 0.016 & 5 & 34 & 11 & 24.915 & 64.09 \\
& $40-50$ & 5.1 & 0.215 & 0.370 & 0.014 & 0.012 & 2 & 31 & 9.5 & 29.585 & 60.92 \\
& $50-60$ & 5.0 & 0.234 & 0.403 & 0.028 & 0.008 & 2 & 34 & 9.25 & 26.51 & 64.24 \\
& $60-70$ & 5.4 & 0.244 & 0.420 & 0.028 & 0.04 & 2 & 30 & 12 & 29.905 & 58.10 \\
& $70-80$ & 5.5 & 0.254 & 0.437 & 0.028 & 0.02 & 1 & 29 & 19.25 & 14.11 & 66.64 \\
& $80-90$ & 5.8 & 0.215 & 0.370 & 0.014 & 0.016 & 1 & 27 & 15 & 28.36 & 56.64 \\
& $90-100$ & 6.0 & 0.205 & 0.353 & 0.014 & 0.012 & 1 & 26 & 16.5 & 27.12 & 56.38 \\
\hline
\end{tabular}

$\mathrm{pH}=\mathrm{pH}(1: 2.5 \mathrm{H} 2 \mathrm{O}), \mathrm{C}=$ Organic carbon (\%), $\mathrm{N}=$ Total nitrogen (\%), $\mathrm{P}=$ Available Bray $\mathrm{P}(\mathrm{mg} / \mathrm{kg}), \mathrm{K}=$ Available Bray $\mathrm{K}(\mathrm{meq} / 100 \mathrm{~g}), \mathrm{MO}=$ organic matter $(\%) \mathrm{CEC}=$ cation exchange capacity $(\mathrm{meq} / 100 \mathrm{~g}), \mathrm{S}=$ Sand $(\%), \mathrm{L}=\mathrm{Silt}$ $(\%), \mathrm{A}=$ Clay $(\%)$, bd= bulk density 
Soil moisture content was measured only in Bambey during the dry seasons of 2014 and 2015. It was measured to a depth of $160 \mathrm{~cm}$ at $10 \mathrm{~cm}$ intervals twice a week by a Diviner 2000. Readings were taken through the wall of a PVC access tube. Data was collected from a network of 24 access tubes installed in site.

Weather stations were located at each site at less than 1kilometre distance from the field experiments. Rainfall, maximum and minimum air temperature, sunshine hours, maximum and minimum relative humidity and wind speed were measured. The rainy season was cooler than the dry season due to a higher relative humidity. The high amount of water during the rainy season was recorded in Sinthiou Sinthiou Malem (696mm). Plants during the dry season 2014 suffered more from heat stress than plants during the dry season 2015 although they received nearly the same amount of water due to difference in sowing date. However, plants received less water in rainy season, therefore they suffered more for water stress than heat stress.

\subsection{Data Analysis}

The data were processed using Sigma plot 12.0 for figures and R 3.2.2 (https://www.r-project.org/) in RStudio, which is an Integrated Development Environment (IDE) for the statistical analysis (Team, 2014). The analysis of variance was used to analyze the differences between treatments. The Tukey's HSD test was performed to determine the significant differences of means between treatments at $5 \%$ after proceeding the analysis of variance (ANOVA).

\section{Results}

\subsection{Field Experiments Analysis}

To assess the effects of fertilizer response and water stress on peanut development, growth and yield in Senegal, we conducted field experiments in three different parts in Senegal.

\subsubsection{Above Ground Biomass (AGB)}

Peanut is an indeterminate plant (Cattan, 1996). The evolution of the total AGB was mostly linear from emergence to maturity during the dry season for all the experiments due to the irrigation effect (Figure 4.a,b,c,d). However, during the rainy season, leaf defoliation at maturity have effect to decline the total AGB (Figure 4.e,f,g). The evolution of the total AGB is father for the early maturity variety (Fleur11) than the medium maturity variety (73-33) for all experiments and for all seasons. However, greater values were recorded for 73-33 at maturity. During the dry season, the percentage of leaf defoliation was small due to the effect of irrigation. Therefore, there was no reduction of total AGB at harvest except in Nioro in dry season 2014 and 2015 for the variety Fleur11. During the rainy season, a period of rapid growth was observed, followed by a decline towards the harvest because of leaf defoliation which decreased by $30 \%$ of the total AGB. During the dry season the total AGB produced was higher in Nioro than Bambey. Furthermore, the total AGB produced during the dry season was greater (maximum value recorded in Nioro 2014 with $8695 \mathrm{~kg} / \mathrm{ha}$ for Fleur 11 and $10271 \mathrm{~kg} / \mathrm{ha}$ for $73-33$ ) than the total AGB produced during the rainy season (minimum value recorded in Bambey 2014 with $3051 \mathrm{~kg} / \mathrm{ha}$ for Fleur 11 and 3264kg/ha for 73-33). 

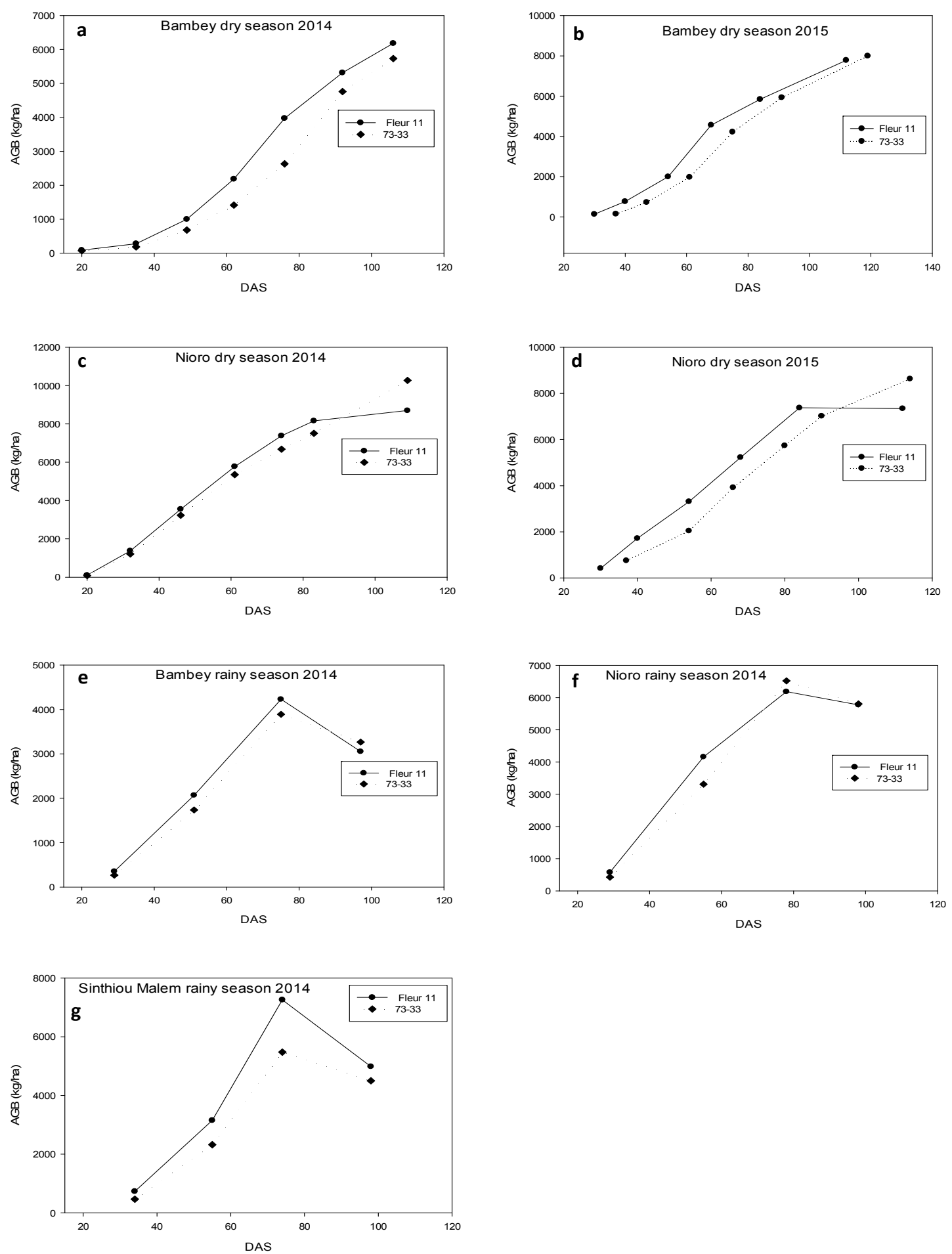

Figure 4. Evolution of above ground biomass (AGB)

\subsubsection{Leaf Area Index (LAI)}

The two varieties showed similar evolution of LAI. However, 73-33 tended to produce higher LAI at the end of the growing season in both dry and rainy season due to the cycle length except in Bambey during the dry season 2014 (Figure 5.a). The LAI increase was linear during the dry season with a slight decline at maturity (Figure $5, a, b, c, d)$. Under rainy season condition, it increased quickly and declined towards maturity.

This phenomenon of decline was also observed during the dry season when the plants were under water stress treatments. However, the effect of fertilization rate did not show any difference between treatments. 

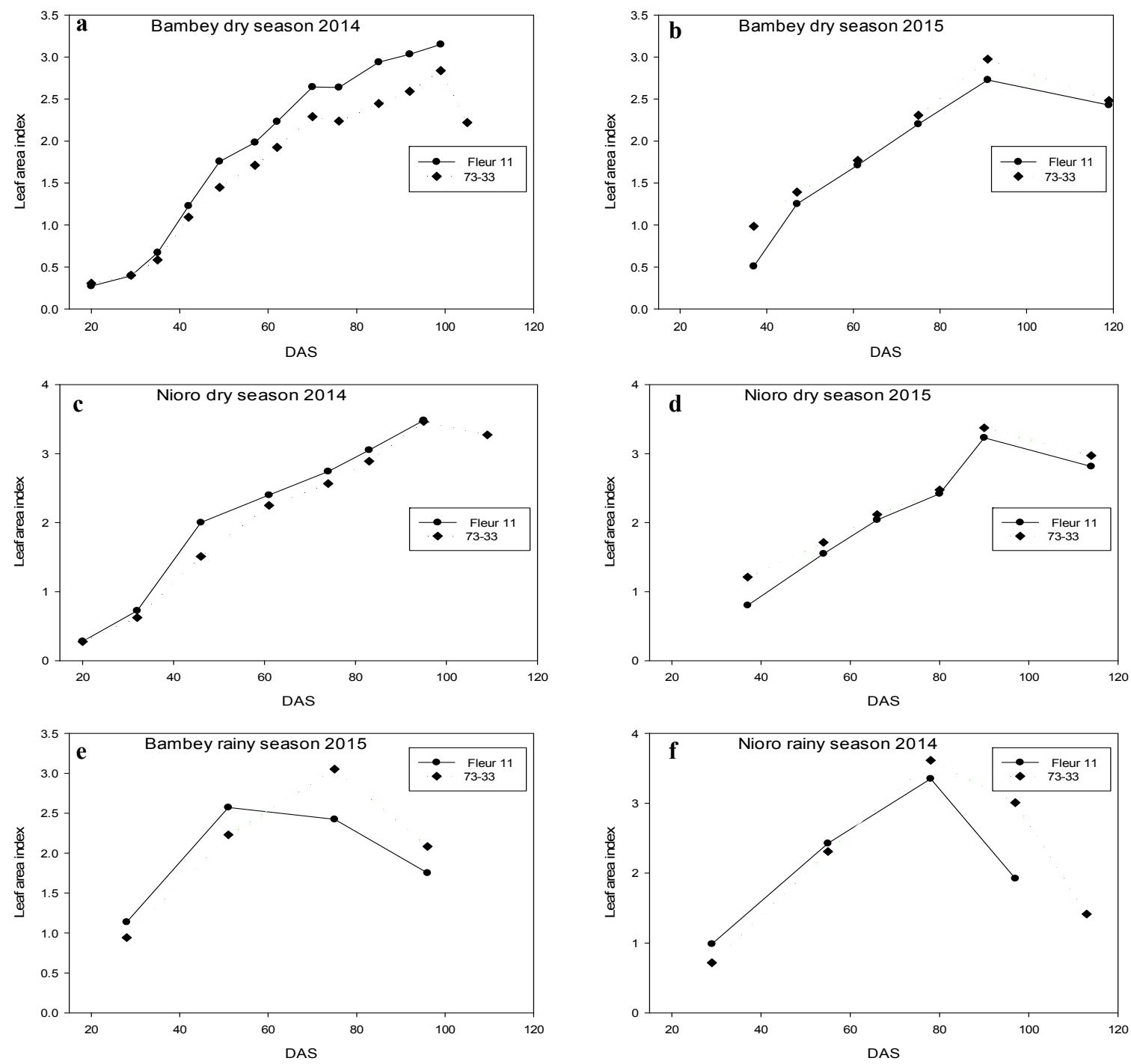

Figure 5. Leaf area index under growing season

\subsubsection{Analysis of Variance (ANOVA)}

The first step for presenting result was to make an ANOVA for all single experiment to determine the interaction between factors. Table 4 and table 5 present a summary of the ANOVA results for biomass and seed yield respectively. 
Table 4. Analysis of variance for biomass yield

\begin{tabular}{|c|c|c|c|c|c|c|c|c|}
\hline Season & Sites & Irrigation & Fertilizer & Variety & $\begin{array}{l}\text { Irrigation } \\
\text { Fertilizer }\end{array}$ & $\begin{array}{l}\text { Irrigation } \\
\text { Variety }\end{array}$ & $\begin{array}{l}\text { Fertilizer } \\
\text { Variety }\end{array}$ & $\begin{array}{l}\text { Irrigation } \\
\text { Fertilizer } \\
\text { Variety }\end{array}$ \\
\hline \multirow{2}{*}{$\begin{array}{l}\text { Dry season } \\
2014\end{array}$} & Bambey & $\bar{S}$ & NS & NS & NS & NS & NS & NS \\
\hline & Nioro & & NS & $\mathrm{S}$ & & & NS & \\
\hline \multirow{3}{*}{$\begin{array}{l}\text { Rainy } \\
\text { season } 2014\end{array}$} & Bambey & & NS & S & & & NS & \\
\hline & Nioro & & NS & $\mathrm{S}$ & & & NS & \\
\hline & Sinthiou & & NS & NS & & & NS & \\
\hline \multirow{2}{*}{$\begin{array}{l}\text { Dry season } \\
2015\end{array}$} & Bambey & S & NS & NS & NS & NS & NS & NS \\
\hline & Nioro & S & NS & $\mathrm{S}$ & NS & NS & NS & NS \\
\hline
\end{tabular}

Table 5. Analysis of variance for seed yield

\begin{tabular}{|c|c|c|c|c|c|c|c|c|}
\hline Season & Sites & Irrigation & Fertilizer & Variety & $\begin{array}{l}\text { Irrigation } \\
\text { Fertilizer }\end{array}$ & $\begin{array}{l}\text { Irrigation } \\
\text { Variety }\end{array}$ & $\begin{array}{l}\text { Fertilizer } \\
\text { Variety }\end{array}$ & $\begin{array}{l}\text { Irrigation } \\
\text { Fertilizer } \\
\text { Variety }\end{array}$ \\
\hline \multirow{2}{*}{$\begin{array}{l}\text { Dry season } \\
2014\end{array}$} & Bambey & $\mathrm{S}$ & NS & $\mathrm{S}$ & NS & $\bar{S}$ & NS & NS \\
\hline & Nioro & & NS & NS & & & NS & \\
\hline \multirow{3}{*}{$\begin{array}{l}\text { Rainy } \\
\text { season } 2014\end{array}$} & Bambey & & NS & $\mathrm{S}$ & & & NS & \\
\hline & Nioro & & NS & $\mathrm{S}$ & & & NS & \\
\hline & Sinthiou & & NS & NS & & & NS & \\
\hline \multirow{2}{*}{$\begin{array}{l}\text { Dry season } \\
2015\end{array}$} & Bambey & $\mathrm{S}$ & NS & NS & NS & NS & NS & NS \\
\hline & Nioro & $\mathrm{S}$ & NS & NS & NS & NS & NS & NS \\
\hline
\end{tabular}

$\mathbf{S}=$ significant, $\mathbf{N S}=$ no significant

\subsection{Effect of Water Stress on Peanut Yield}

The results presented in this section regarded experiments conducted in dry season 2014 and 2015 in Bambey and in Nioro 2015. A split plot design was used for these experiments.

\subsubsection{Biomass Yield}

Biomass yield was higher in Bambey than Nioro during the dry season in 2015 under full irrigation treatment ET0 and ET1 (Figure 6) for both varieties except for 73-33 under ET0 treatment. In opposite, for the stress treatment S1T0, S1T1, S2T0 and S2T1, it was higher in Nioro than in Bambey due to duration where plants were exposed under drought which was longer in Bambey (25 days) than in Nioro (20). The comparison of the two seasons in Bambey showed that biomass was higher in year 2015 than in year 2014 under full irrigation and stress conditions (Figure 6.a,b). The temperatures during the growth season were lower in year 2015, where peanut was showed in February. The treatments were significantly different $(\mathrm{p}<0.05)$ for irrigation level $(\mathrm{E}, \mathrm{S} 1$ and S2) under dry season 2014 and 2015 for both sites (table 4) with the greatest mean values observed in field capacity irrigation (E) followed by the first stress (S1) and then the second stress (S2). Any significant difference between fertilizer levels was observed in both Bambey and Nioro, as well as for the interaction between fertilizer levels and varieties. Difference between varieties was observed in Nioro 2015 (Table 4). However, a comparison of the analysis of variance between the two sites in 2015, showed a significant difference between sites, between varieties, between irrigation, between variety and sites and between irrigation and sites (Table 6). 
Table 64. ANOVA for the biomass yield between Bambey and Nioro for the dry season 2015

\begin{tabular}{lrrrrrl}
\hline & Df & Sum Sq & Mean Sq & F value & Pr $(>\mathrm{F})$ & \\
\hline Variety & 1 & 9006201 & 9006201 & 9.169 & 0.00341 & $* *$ \\
Fertilizer & 1 & 1256208 & 1256208 & 1.279 & 0.26184 & \\
Irrigation & 2 & 135581676 & 67790838 & 69.019 & $<2 \mathrm{e}-16$ & $* * *$ \\
Site & 1 & 8584792 & 8584792 & 8.74 & $4.21 \mathrm{E}-03$ & $* *$ \\
Variety:Fertilizer & 1 & 526263 & 526263 & 0.536 & 0.46656 & \\
Variety:Irrigation & 2 & 1493782 & 746891 & 0.76 & 0.47119 & \\
Fertilizer:Irrigation & 2 & 1553950 & 776975 & 0.791 & 0.45727 & \\
Variety:Site & 1 & 5154473 & 5154473 & 5.248 & 0.0249 & $*$ \\
Fertilizer:Site & 1 & 1869507 & 1869507 & 1.903 & 0.17197 & \\
Irrigation:Site & 2 & 25136656 & 12568328 & 12.796 & $1.76 \mathrm{E}-05$ & $* * *$ \\
Var:Fert:Irri & 2 & 109224 & 54612 & 0.056 & 0.94596 & \\
Var:Fert:Site & 1 & 1515597 & 1515597 & 1.543 & 0.21819 & \\
Var:Irri:Site & 2 & 834412 & 417206 & 0.425 & 0.65555 & \\
Fert:Irri:Site & 2 & 1710738 & 855369 & 0.871 & 0.42295 & \\
Var:Fert:Irri:Site & 2 & 44165 & 22083 & 0.022 & 0.97777 & \\
Residuals & 72 & 70718621 & 982203 & & & \\
\hline
\end{tabular}

Var $=$ Variety, Irri $=$ Irrigation, Fert $=$ Fertilizer
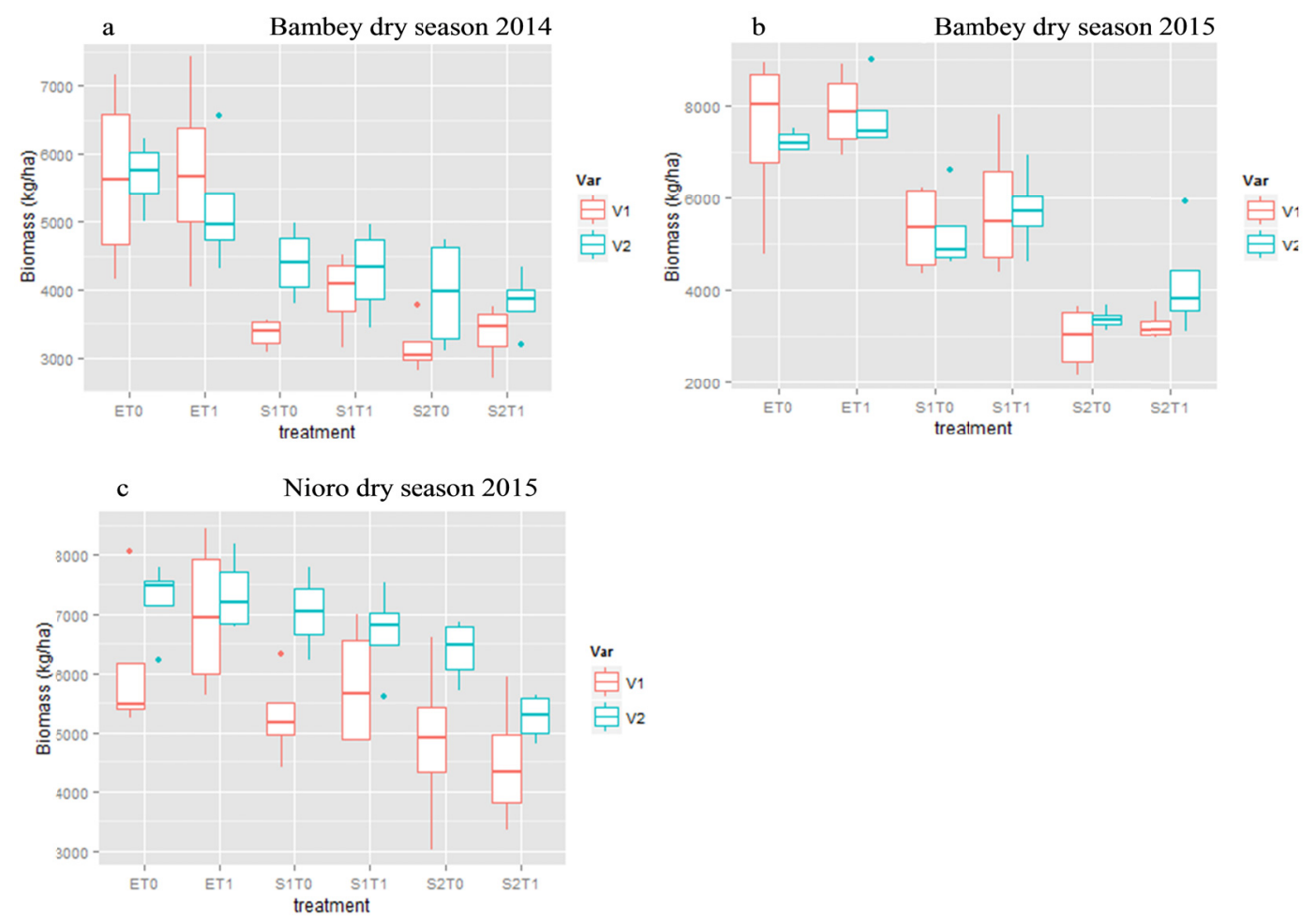

Figure 6. Biomass yield under different irrigation regimes

\subsubsection{Seed Yield}

Under full irrigation application seed yield varied between $2000 \mathrm{~kg} / \mathrm{ha}$ to $2500 \mathrm{~kg} / \mathrm{ha}$ for both seasons and both varieties excepted for 73-33 in Bambey in 2014 (Figure 7.a). Under stress condition higher values of seed yield 
were recorded in Nioro 2015 for both S1 and S2 (Figure 7.c). In both sites seed yield was higher under full irrigation followed by S1 and S2 (Figure 7). The analysis of variance in each site showed a significant difference for irrigation in both sites and in both seasons, while, any difference were observed for fertilizer. In Bambey 2014, a significant difference was observed between varieties and the interaction between variety and irrigation (Table5). The results in Bambey 2014 and 2015 showed that higher values was recorded in year 2015 than in year 2014 under full irrigation and S1 and S2 conditions.

However, a comparison between the two sites in 2015, showed a significant difference between irrigation, between sites and between site and irrigation (Table 7).

Table 7. Seed yield interaction between Bambey and Nioro under dry season 2015

\begin{tabular}{lrrrrr}
\hline & Df & Sum Sq & Mean Sq & F value & $\operatorname{Pr}(>\mathrm{F})$ \\
\hline Variety & 1 & 6095 & 6095 & 0.072 & 0.788734 \\
Fertilizer & 1 & 67501 & 67501 & 0.801 & 0.373759 \\
Irrigation & 2 & 37728097 & 18864049 & 223.866 & $<2 \mathrm{e}-16$ *** \\
Site & 1 & 1007315 & 1007315 & 11.954 & $0.000919 * * *$ \\
Variety:Fertilizer & 1 & 3925 & 3925 & 0.047 & 0.82973 \\
Variety:Irrigation & 2 & 87740 & 43870 & 0.521 & 0.596372 \\
Fertilizer:Irrigation & 2 & 17375 & 8688 & 0.103 & 0.90217 \\
Variety:Site & 1 & 26424 & 26424 & 0.314 & 0.577228 \\
Fertilizer:Site & 1 & 46463 & 46463 & 0.551 & 0.460163 \\
Irrigation:Site & 2 & 562212 & 281106 & 3.336 & $0.041157 *$ \\
Var:Fert:Irri & 2 & 6295 & 3148 & 0.037 & 0.963353 \\
Var:Fert:Site & 1 & 16948 & 16948 & 0.201 & 0.655155 \\
Var:Irri:Site & 2 & 3552 & 1776 & 0.021 & 0.97915 \\
Fert:Irri:Site & 2 & 102179 & 51090 & 0.606 & 0.548126 \\
Var:Fert:Irri:Site & 2 & 78252 & 39126 & 0.464 & 0.630431 \\
Residuals & 72 & 6067065 & 84265 & & \\
\hline
\end{tabular}



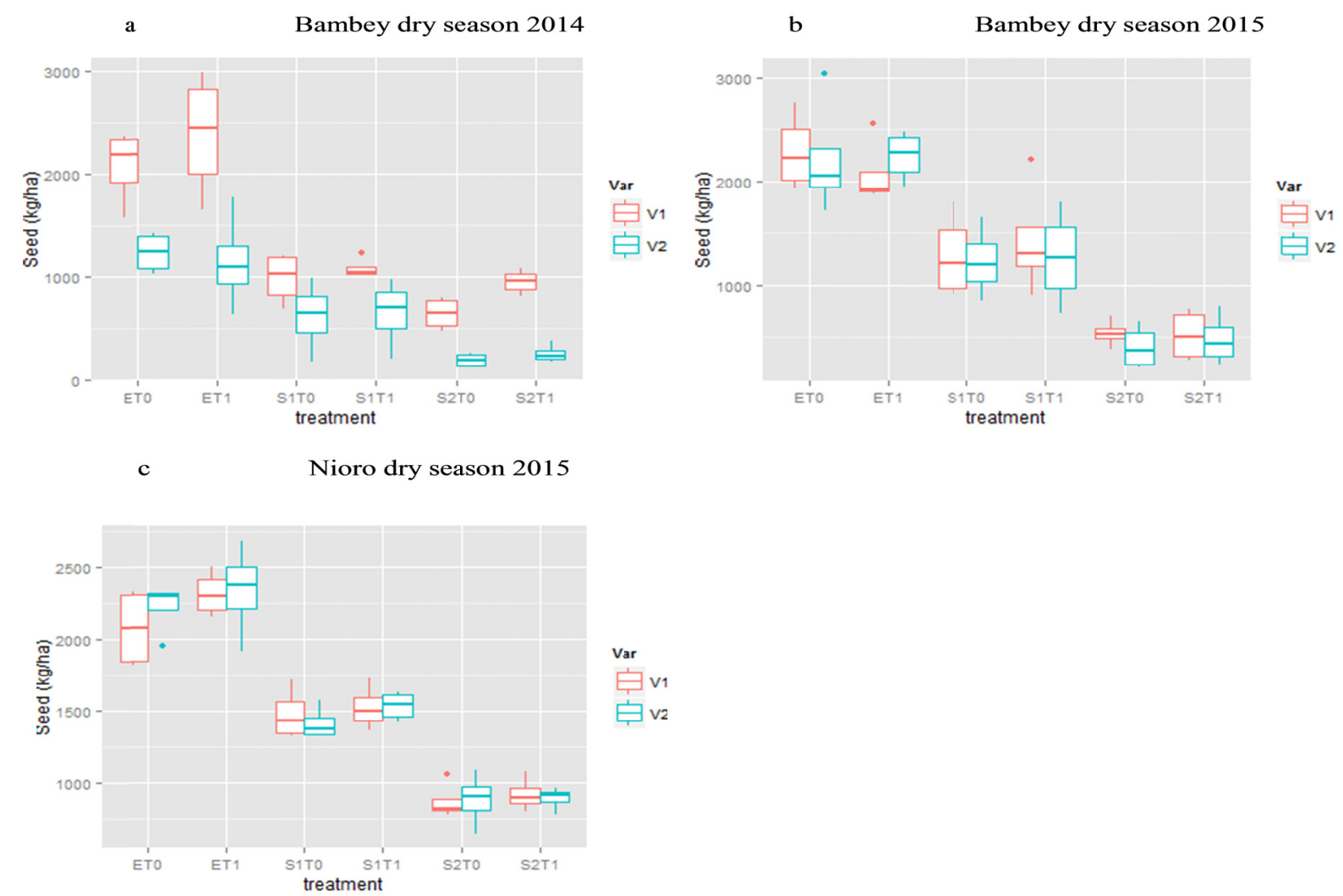

Figure 7. Seed yield under different irrigation regimes

\subsection{Effect of Fertilization Rate on Peanut Yield}

Datasets for field experiments conducted during the dry season 2014 in Nioro and the rainy season in Bambey, Nioro and Sinthiou Malem 2014 were used in a randomized complete block design (RCBD) with four replications.

\subsubsection{Biomass Yield}

Aboveground biomass was greater during the dry season (Figure 8.d) than the rainy season (Figure 8.a,b,c). Any difference were observed between the fertilizer levels in all sites and in both seasons. However greater values were recorded in treatment with fertilizer application T1 for Fleur 11 and T4 for 73-33 in Bambey (Figure 8.a), T5 for both Fleur 11 and 73-33 in Nioro (Figure 8.b), T5 for both Fleur 11 and 73-33 in Sinthiou Malem (Figure 8.c), T3 for both Fleur 11 and 73-33 in Nioro in dry season 2014 (Figure 8d). Significant difference between varieties was recorded in Nioro during the dry season 2014 and in Bambey and Nioro during the rainy season 2014, whereas in Sinthiou Malem any difference was observed. Nevertheless, higher values of biomass were recorded in Sinthiou Malem during the rainy season 2014 with a maximum value for Fleur11, of $4500 \mathrm{~kg} / \mathrm{ha}$ and $5200 \mathrm{~kg} / \mathrm{ha}$ for 73-33 compared to Bambey and Nioro (Figure 8. a, b, c). Table 8 presents an analysis of the interaction between sites under rainy season condition. It showed a significant site effect on biomass and a significant difference between varieties and sites. 
Table 8. Biomass yield interaction in three different sites in rainy season

\begin{tabular}{llllcl}
\hline & Df & Sum Sq & Mean Sq & F value & $\operatorname{Pr}(>\mathrm{F})$ \\
\hline Variety & 1 & 764491 & 764491 & 1.634 & 0.20389 \\
Fertilizer & 5 & 4316427 & 863285 & 1.845 & 0.1101 \\
Site & 2 & 134453126 & 67226563 & 143.68 & $<2 \mathrm{e}-16^{* * *}$ \\
Variety: Fertilizer & 5 & 2590121 & 518024 & 1.107 & 0.36091 \\
Variety:Site & 2 & 5464224 & 2732112 & 5.839 & $0.00391^{* *}$ \\
Fertilizer:Site & 10 & 6681037 & 668104 & 1.428 & 0.17767 \\
Variety:Fertilizer:Site & 10 & 3699469 & 369947 & 0.791 & 0.63768 \\
Residuals & 108 & 50530028 & 467871 & & \\
\hline
\end{tabular}
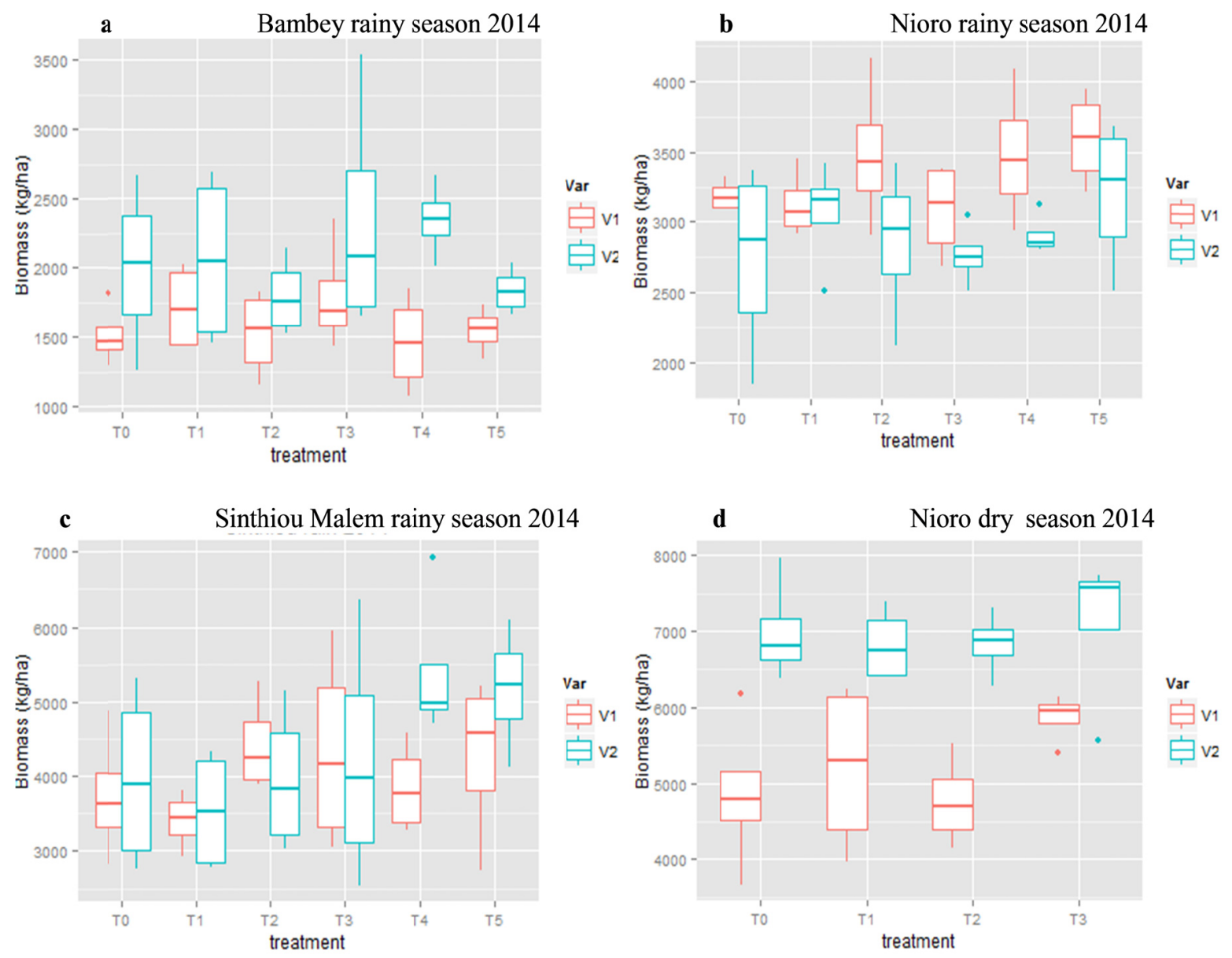

Figure 8. Biomass yield for fertilization rate evaluation

\subsubsection{Seed Yield}

Seed yield was lower in Bambey followed by Sinthiou Malem and than in Nioro under rainfed condition (Figure 9.a,b,c). The ANOVA showed a significant difference between varieties for Bambey and Nioro, whereas there was no significant difference between varieties in Sinthiou Malem and Nioro during the dry season 2014 (Table 5). During the rainy season, the variety Fleur 11 gave higher yield than 73-33 in all fertilizer levels in Bambey (Figure 9.a), in opposite in Nioro where the variety 73-33 gave higher yield than Fleur 11 (Figure 9.b) for all fertilizer levels. While in Sinthiou Malem these difference between variety were not significant (Figure 9.c). In Nioro during the dry season 2014 no significant difference was showed between varieties but the variety Fleur 11 
gave slightly high yield for all the fertilizer level (Figure 9.d) with a maximum mean value of $2615 \mathrm{~kg} / \mathrm{ha}$ for T3 level.

The fertilizer response was not significant at any sites, as well as the interaction between variety and fertilizer level. A significant difference between sites and between varieties and sites was observed for seed yield while there were no differences for the interaction between variety, fertilizer and site (Table 9).

Table 9. Seed yield interaction in three different sites in rainy season 2014

\begin{tabular}{lrrrrrr}
\hline & Df & Sum Sq & Mean Sq & F value & $\operatorname{Pr}(>\mathrm{F})$ & \\
\hline Variety & 1 & 39419 & 39419 & 0.404 & 0.527 \\
Fertilizer & 5 & 216479 & 43296 & 0.443 & 0.817 \\
Site & 2 & 27107482 & 13553741 & 138.823 & $<2 \mathrm{e}-16$ *** \\
Variety: Fertilizer & 5 & 526490 & 105298 & 1.079 & \\
Variety: Site & 2 & 2686364 & 1343182 & 13.757 & $4.76 \mathrm{e}-06$ *** & \\
Fertilizer: Site & 10 & 1431817 & 143182 & 1.467 & 0.376 \\
Var: Ferti: Site & 10 & 999769 & 99977 & 1.024 & 0.428 \\
Residuals & 108 & 10544388 & 97633 & & \\
\hline
\end{tabular}
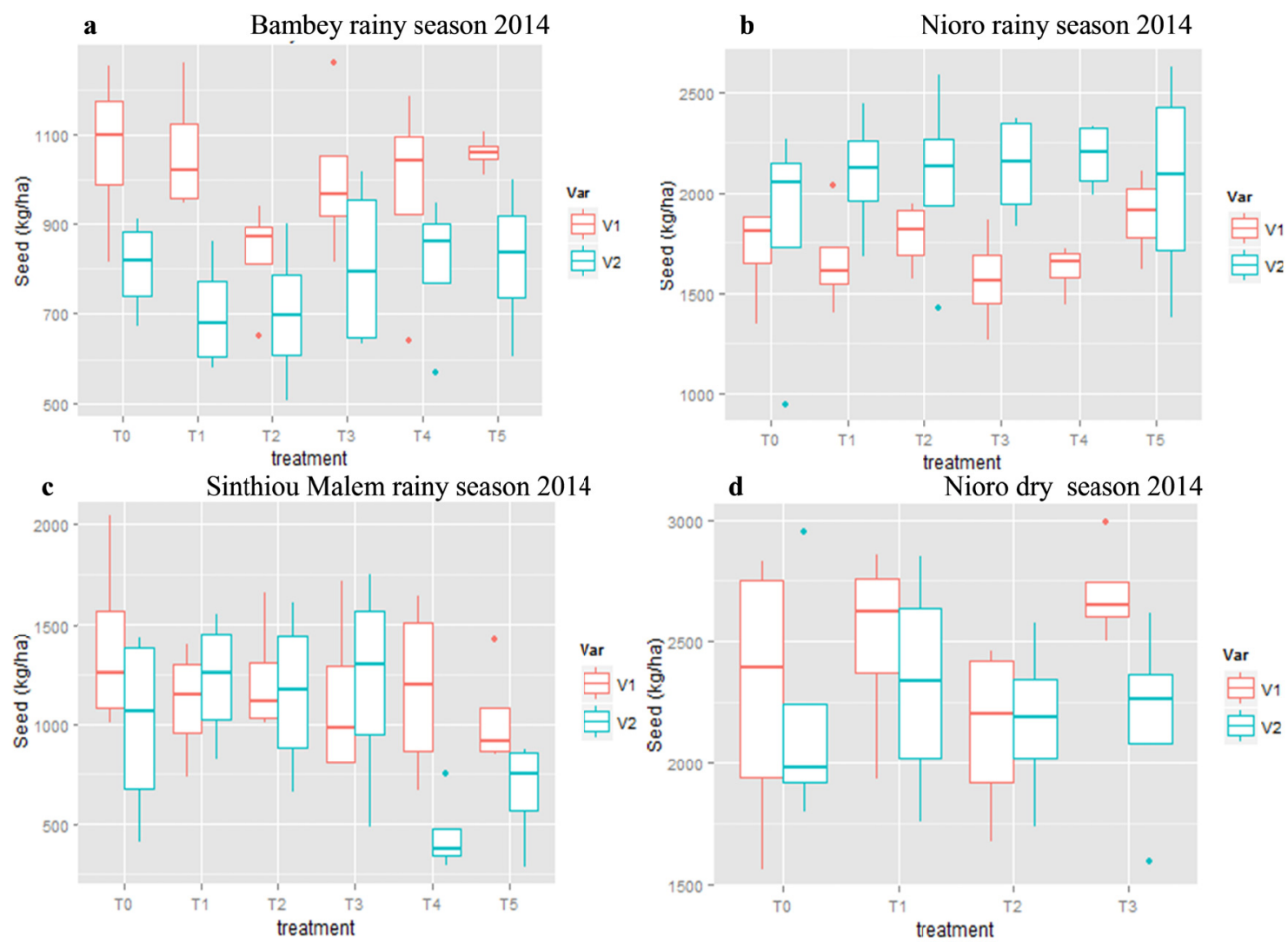

Figure 9. Seed yield for fertilization rate evaluation

\section{Discussion}

A low content of organic carbon in Bambey in the top $50 \mathrm{~cm}$ could be attributed to the low contain of soil residues and the high percentage of soil degradation which was already shown by (Diouf, 2000). While in Nioro the higher value of organic carbon could be explained by the effect of soil residues because of the fallow in 2014 . 
The smaller quantity of organic carbon, in Bambey is associated also to a smaller clay contain $(5.65 \%)$ which explains the low cation-exchange capacity (CEC). The higher percentage of sand in Bambey explains the low capacity of soil to retain water. In contrast, in Nioro the medium clay contain $(10.1 \%)$ in the top soil explains the higher values of CEC.

The low $\mathrm{pH}$ value recorded in both sites explains the low amount of base cations due to leaching. The low values of $\mathrm{pH}$ were reported by (Sarr et al., 1999) for the soil in Bambey. The smaller quantity of total soil nitrogen content $(0.02 \%)$ in Bambey was as a result of the smaller quantity of the soil organic matter (SOC), which was due to crop residue deficiencies contrary in Nioro. The phosphorus content was higher in both sites. It could be attributed in Bambey 2014 to the phosphorus uptake by the previous millet grew in rainy season 2013 and previous maize grew in rainy season 2014 in Nioro 2015 which values were above the threshold of phosphorus deficiencies (Diouf, 2000).

The decline of peanut production through recent decades (DAPSA., 2014) was mostly explained by lack of input, soil degradation and limited water availability (Montfort, 2005).

These two varieties grown during the field experiments are drought tolerant and they are part of the most varieties with high yield most grown in the country.

Drought stress was known to substantially reduce peanut yield when it occurred at reproductive stage (Annerose, 1990; Cecilia et al., 2013; Pandey et al., 2001; Reddy et al., 1996; Wright et al., 1991; Wright and Rao, 1994; Yao et al., 1982).

The substantial reduction of biomass yield, pod yield and kernel yield were recorded in all the water stress treatment in two different reproductive stages of the growth of peanut. These are in the agreement with results obtained by (Annerose, 1985) which showed that biomass and pod yield is linear according to the quantity of water received.

The yield obtained at field capacity irrigation for the two varieties showed a good biomass, pod and seed production with an average of $6500 \mathrm{~kg} / \mathrm{ha}, 3500 \mathrm{~kg} / \mathrm{ha}$ and $2000 \mathrm{~kg} / \mathrm{ha}$ respectively. This was different from the production in stress phases. The variety Fleur11 produced more biomass than the variety 73-33 in Bambey whereas the varieties 73-33 produced more biomass than Fleur 11 in Nioro. It could be related by the fact that the Fleur 11, known by early maturity, adapted more in Bambey than in Nioro. However, under rainfed condition, these differences could be attributed to the higher amount of water received in Nioro than in Bambey which allow medium cycle variety (73-33) to complete its growth.

The higher biomass yield observed during the full irrigation followed by the stress application during the flowering period in Bambey. In Nioro, biomass was also higher in full irrigation followed by the first stress application with a high biomass in Nioro than in Bambey in stress application. The difference was attributed to the duration of stress on plants which was longer in Bambey (25days) than in Nioro (20days).

Pod yield and seed yield observed are also lowest during the second stress application (at maturation stage) than the first stress (at flowering stage) with a reduction of $50 \%$ and $33 \%$ of the seed yield observed (Figure 6.a.b.c) respectively. These differences might have occurred due to the fact that after re-watering plants during the first stress, peanut still producing flower and was able to recover and produce yield. Similar observations were reported for Bambara groundnut in Botswana by (Vurayai et al., 2011).

The amount of yield losses is function of number of days stress and the period of stress application.

Vaghasia et al. (2010) established that the stress at flowering stage (25-47 days after sowing) and pod development stage (50-72 days after sowing) gave $18.45 \%$ and $30.63 \%$ reduction in pod yield than no water stress treatment, respectively. Kernel yield decreased by $28 \%, 36 \%$ and $41 \%$ in deficit-irrigated late vegetative and early flowering, late flowering and early pegging, pegging and pod formation growth stages, respectively compared with full irrigation treatment (Kheira, 2009). The reduction of yield for peanut due to water stress is known to occur during the pod filling stage (Rao et al., 1974; Vaghasia et al., 2010; Vurayai et al., 2011) which was confirmed in this study at both sites and both varieties. However, the water stress management could depend on the variety cycle. In this study the reduction of the pod and seed yield is less affected by the Fleur 11 variety than the 73-33 variety. It could be explained by the fact that the Fleur11 variety achieved the physiological maturity faster than the 73-33 variety. Therefore, water deficit reduced pod and seed yield by causing smaller and younger pods to terminate the growth and eventually by reducing the growth rate of old pod. These results were corroborated by (Rao et al., 1985) in India.

The stress application on the flowering stage and the pod filling stage was justified by the fact that peanut was most sensitive for these periods to water stress (Billaz and Ochs, 1961; Black et al., 1985; Nageswara Rao et al., 
1985; Patel and Golakiya, 1991; Reddy et al., 2003; Stirling et al., 1989) where the greatest reduction in kernel yield occurred when stress was imposed during the seed filling phase.

Most of the flowers did not form pegs during the stress at the flowering period (30-45 days after sowing) but flowers produced after re-watering compensated for this loss (Gowda and Hegde, 1986). It confirms the greater yield obtained during the flowering period compared to the yield obtained during the pod and seed filling in the experimental sites.

It is observed a slight increase of biomass, pod and seed yield when fertilizer was applied but no significant difference was observed between fertilizer level applications. There was also no significant difference between the interaction fertilizer and irrigation. The lowest difference may be explained by the lowest quantity of NPK applied which contained $9 \mathrm{~kg} / \mathrm{ha}$ of nitrogen $14 \mathrm{~kg} / \mathrm{ha}$ of phosphorus and $9 \mathrm{~kg} / \mathrm{ha}$ of potassium.

Peanut response to NPK fertilizer was studied in Nioro during the dry season 2014 and in Bambey, Nioro and Sinthiou Malem during the rainy season 2014. In Sinthiou Malem, low harvest yield could be attributed to the dry spell that occurred earlier in October when plants were at maturity stage (seed filling) while in Bambey the low harvest could be explained by the low quantity of water received during the rainy season 2014 (407mm).

There were any significant responses of fertilizer in all sites. However, the plot with fertilizer application resulted in the greatest biomass yield, pod yield and seed yield. These results showed that the quantity of fertilizer used was not in the optimum dose to determine a difference between fertilizer level on one hand and on other hand, the initial soil properties contained considerable quantity of nutrients. This may be because the experiments were conducted at field research stations which received ample fertilization. However, the quantity of nitrogen used was sufficient ( $9 \mathrm{~kg} / \mathrm{ha}$ ) because of the capacity of peanut to fix nitrogen. Campbell et al. (1980) showed that there was no significant difference in kernel yield from plot received 10,50 and $100 \mathrm{~kg} / \mathrm{ha}$ of nitrogen. Therefore, it is an economic disadvantage for increasing nitrogen levels beyond $10 \mathrm{~kg} / \mathrm{h}$. In addition, organic amendments increased microbial population and resulted in a positive correlation between population of symbiotic bacteria and nitrogen fixation. Similar observations were reported by (Lee et al., 2004; Limtong and Piriyaprin, 2006). This could also be explained by the higher nitrogen contain in Bambey and Nioro with received $5750 \mathrm{~kg} / \mathrm{ha}$ of cow manure incorporated in the soil before sowing in the year 2014 .

The quantity of phosphorus used was too low to give a response on peanut growth where the appropriate application rate for peanut is $60 \mathrm{~kg} \mathrm{P}_{2} \mathrm{O}_{5} /$ ha for poor alluvial soils and $90 \mathrm{~kg} \mathrm{P}_{2} \mathrm{O}_{5} /$ ha for sandy soils (Ha, 2003; Mirvat et al., 2006; Ogeh and Oyibo, 2015). Naab et al. (2009) demonstrated positive effects of phosphorus application from $30 \mathrm{~kg} / \mathrm{ha}$ on biomass and seed yield but no difference was found between $30 \mathrm{kgP} / \mathrm{ha}$ and $60 \mathrm{kgP} / \mathrm{ha}$ application and between $60 \mathrm{kgP} / \mathrm{ha}$ and $90 \mathrm{kgP} / \mathrm{ha}$ application on farm experiments in Ghana.

\section{Conclusion}

Field experiments were carried out in three different agro-climatic zones in Senegal. Results of assessing the effect of water stress on peanut and the fertilizer rate response indicated that the reduction of peanut yield was highly associated to water stress than to fertilizer application for the range of conditions considered. Therefore, addressing the issues of water stress is pivotal in increasing the yield of peanuts as opposed to fertilizer application. Furthermore, the quantity of fertilizer applied was insufficient to show a difference between the fertilizer levels and the interaction between irrigation and fertilizer during the two growth seasons. Thus, adequate fertilizer application at the right dose and time could influence the performance of the peanut. From this point of view, the application of fertilizer should be split in different phases of the growing season but not only applied just after sowing.

Further investigations have to be made to test higher single dose of nitrogen or phosphorus or potassium in split applications. After successful results are obtained, in an ideal field based situation they can be evaluated under limited water conditions. This investigation could further be conducted in field based conditions where limited soil nutrients occur.

\section{Acknowledgments}

This work was funded by German Federal Ministry of Education and Research (BMBF) through the West Africa Science Service Center on Climate Change and Adapted Land Use (WASCAL).

\section{References}

AGETIP. (1995). Programme de réhabilitation des stations ISRA. Informations pédologiques et étude cartographique des sols de la station de Nioro. 
Annerose, J. M. D. (1985). Réponses d'une variété d'arachide soumise à des sécheresses d'intensité croissante durant différentes phases de son cycle. Dot. ISRA/CNRA Bambey. 41.

Annerose, J. M. D. (1988). Critères physiologiques pour l'amélioration de l'adaptation a la sécheresse de l'arachide, Oléagineux, Vol. 43, numéro 5 6p.

Annerose, J. M. D. (1990). Recherches sur les mécanismes physiologiques d'adaptation à la sécheresse. Application au cas de l'arachide (Arachis hypogea L.) cultivée au Sénégal. Paris VII University

Bankole, S., \& Adebanjo, A. (2004). Mycotoxins in food in West Africa: current situation and possibilities of controlling it. African Journal of Biotechnology, 2, 254-263.

Billaz, R., \& Ochs, R. (1961). Stages of susceptibility of groundnut to drought oleaginous. 605-611.

Black, C., Tang, D. Y., Ong, C., Solon, A., \& Simmonds, L. (1985). Effects of soil moisture stress on the water relations and water use of groundnut stands. New phytologist, 100, 313-328. https://doi.org/10.1111/j.1469-8137.1985.tb02781.x

Boote, K. J. (1982). Growth stages of peanut (Arachis hypogaea L.). Peanut science 35-49.

Campbell, V. A., Wahab, A. H., \& Murray, H. (1980). Response of peanut (Arachis hypogaea L.) to nitrogen, minor elements and phosphorus fertilization on a newly terraced ultisol in Jamaica. In "Legume Seminar.,(Jamaica)., 28 Feb 1980..".

Cattan, P. (1996). The components of groundnut yield, Agriculture et Development,33-38

Cecilia, M. T. S., Ayman, S., Jakarat, A., Ian, F., \& Gerrit, H. (2013). Scheduling irrigation with a dynamic crop growth model determining the relation between simulated drought stress and yield for peanut. Irri Sci 889-901.

Clavel, D., Baradat, P., Khalfaoui, J. L., Drame, N. K., Diop, N. D., Diouf, O., \& Zuily-Fodil, Y. (2007). Adaptation à la sécheresse et création variétale : le cas de l'arachide en zone sahélienne. Deuxième partie : une approche pluridisciplinaire pour la création variétale 16.

Clavel, D., Drame, N. K., Diop, N., \& Zuily-Fodil, Y. (2005). Adaptation à la sécheresse et création variétale : le cas de l'arachide en zone sahélienne. Première partie : revue bibliographique. OCL 2005, 249-260. https://doi.org/10.1051/ocl.2005.0248

DAPSA. (2014). Direction de l'Analyse, de la Prévision et des Statistiques Agricoles. Résultats définitifs de la campagne agricole. 16.

Diouf, O. (2000). Réponses agrophysiologiques du mil (Pennisetum glaucum (L.) R. Br.) à la sécheresse: influence de la nutrition azotée. Thèse de Doctorat, Université libre de Bruxelles, 160p.

Foncéka, D. (2010). Elargissement de la base génétique de l'arachide cultivée (Arachis hypogaea): Applications pour la construction de populations, l'identification de QTL et l'amélioration de l'espèce cultivée, Montpellier University.

Ganry, F., \& Gueye, F. (1992). La mise en valeur des bas-fonds de la zone soudano-sahélienne par Sesbania rostrata est-elle possible? L'agronomie Tropicale 46, 155-159.

Gautreau, J. (1982). Améliorations agronomiques par le développement de variétés d'arachide adaptées aux contraintes pluviométriques. Oléagineux. 469-475.

Gaye, M. (2013). Le Sénégal pourra-t-il revivre sa belle économie arachidière, Communication personnelle. 18 e Mardi du BAME, Thème : la filière arachidière au Sénégal, Communication orale. 27 Août 2013, ISRA, Dakar.

Gowda, A., \& Hegde, B. (1986). Moisture stress and hormonal influence on the flowering behavior and yield of groundnut (Arachis hypogaea L.). Madras Agric. J 73, 82-86.

Ha, T. T. T. (2003). Effect of phosphorus fertilizer on groundnut yield in poor alluvial and sandy soils of Thua Thien Hue. Better Crops International 17, 16.

Hemalatha, S., Rao, V. P., Padmaja, J., \& Suresh, K. (2013). An overview on role of Phosphorus and Water Deficits on growth, yield and quality of Groundnut (arachis hypogaea L.). International Journal of Applied Biology and P... 
Jongrungklang, N., Toomsan, B., Vorasoot, N., Jogloy, S., Boote, K., Hoogenboom, G., \& Patanothai, A. (2013). Drought tolerance mechanisms for yield responses to pre-flowering drought stress of peanut genotypes with different drought tolerant levels. Field Crops Research 144, 34-42. https://doi.org/10.1016/j.fcr.2012.12.017

Kambiranda, D. M., Vasanthaiah, H. K., Katam, R., Ananga, A., Basha, S. M., \& Naik, K. (2011). Impact of drought stress on peanut (Arachis hypogaea L.) productivity and food safety. Plants and Environment. In Tech Publisher.(http://www. intechopen. com/books/plants-and-environment/impact-of-drought-stress-onpeanut-arachis-hypogaea-l-productivi ty-and-food-safety), 249-272.

Kenchanagoudar, G., Nigam, S., \& Chennabyregowda, M. (2002). Effect of drought on yield and yield attributes of groundnut. Karnataka Journal of Agricultural Sciences 15, 364-366.

Kheira, A. A. A. (2009). Macromanagement of deficit-irrigated peanut with sprinkler irrigation. Agricultural water management 96, 1409-1420. https://doi.org/10.1016/j.agwat.2009.05.002

LAI-2000. (1992). Plant Canopy Analyser, Operating Manuel. LI-COR, Inc, USA, 179p.

Lee, J., Park, R., Kim, Y., Shim, J., Chae, D., Rim, Y., \& Kyoon, B. (2004). Effect of food waste compost on microbial population, soil enzyme activity and lettuce growth. Bioresource Technol 93, 21-28. https://doi.org/10.1016/j.biortech.2003.10.009

Limtong, P., \& Piriyaprin, S. (2006). Effect of compost with chemical fertilizer on biological properties in different fertility soil. 10p.

Martin, J., Bâ, A., Dimanche, P., \& Schilling, R. (1999). Comment lutter contre la contamination de l'arachide par les aflatoxines? Expériences conduites au Sénégal. Agriculture et développement, 58-67.

Meier, U. (2001). Stades phénologiques des mono-et dicotylédones cultivées BBCH Monographie, 2e éd., Uwe Meier (réd.). Centre fédéral de recherches biologiques pour l'agriculture et les forêts.

Mirvat, E. G., Magda, H. M., \& Tawfik, M. M. (2006). Effect of Phosphorus Fertilizer and Foliar Spraying with Zinc on Growth, Yield and Quality of Groundnut under Reclaimed Sandy Soils. Journal of Applied Science Research, 491-496.

Montfort, M. A. (2005). Filières oléagineuses africaines. Notes et Études Économiques n॰23, Septembre. 55-85.

Naab, J., Boote, K., Jones, J., \& Porter, C. H. (2015). Adapting and evaluating the CROPGRO-peanut model for response to phosphorus on a sandy-loam soil under semi-arid tropical conditions. Field Crops Research 176, 71-86. https://doi.org/10.1016/j.fcr.2015.02.016

Naab, J., Prasad, P., Boote, K., \& Jones, J. (2009). Response of Peanut to Fungicide and Phosphorus in On-station and On-farm Tests in Ghana. Peanut Science 36, 157-164. https://doi.org/10.3146/PS08-017.1

Nageswara Rao, R., Singh, S., Sivakumar, V., Srivastava, K., \& Williams, J. (1985). Effect of Water Deficit at Different Growth Phases of Peanut. I. Yield Responses. 5p.

Nautiyal, P., Joshi, Y., \& Dayal, D. (2002). Response of groundnut to deficit irrigation during vegetative growth. Food and Agricultural Organization of the United Nations (FAO)(ed.), Deficit Irrigation Practices. Rome, Italy, 39-46.

Noba, K., Ngom, A., Guèye, M., Bassène, C., Kane, M., Diop, I., Ndoye, F., Mbaye, M. S., Kane, A., \& Ba, A. T. (2014). L'arachide au Sénégal : état des lieux, contraintes et perspectives pour la relance de la filière. OCL 2014, 21(2) D205), 5p. https://doi.org/10.1051/ocl/2013039

Ogeh, J. S., \& Oyibo, R. O. (2015). Phosphorus Fertilization Under Different Land Preparation Methods and Performance of Groundnut (Arachis hypogea L.) in Rainforest Zone of Southern Nigeria. Jurnal TANAH TROPIKA (Journal of Tropical Soils) 19, 1-7.

Pandey, V., Shekh, A. M., Vadodaria, R. P., \& Bhat, B. K. (2001). Evaluation of CROPGRO-Peanut model for two genotypes under different environments. Paper presented at the National seminar on Agro Meteorological Research for Sustainable Agricultural Production at GAU Anand.

Patel, M. S., \& Golakiya, B. A. (1991). Effect of water stress on yield and yield attributes of groundnut (Arachis hypogaea L.). Madras Agricultural Journal, 178-181.

Pélissier, P. (1966). "Les paysans du Sénégal," Imprimerie Fabrègue Saint Yrieux.

Prasad, P. V., Kakani, V. G., \& Upadhyaya, H. D. (2010). Growth and production of groundnut.UNESCO Encyclopedia, 1-26. 
Rao, I. V. S., L., N. R., \& R., a. U. (1974). Effect of moisture stress at different growth stages on yield and oil content of groundnut. The Andhra Agricultural Journal 21, 111-116.

Rao, R., Singh, S., Sivakumar, M., Srivastava, K., \& Williams, J. (1985). Effect of water deficit at different growth phases of peanut. I. Yield responses. Agronomy Journal 77, 782-786. https://doi.org/10.2134/agronj1985.00021962007700050026x

Reddy, P., Reddy, B., Praveen Rao, V., \& Sarma, P. S. (1996). Effect of water deficits at different crop growth periods on growth and yield of groundnut. Journal of Research, Acharya N. G. Ranga Agricultural University 24(2), 147-149.

Reddy, T., Reddy, V., \& Anbumozhi, V. (2003). Physiological responses of groundnut (Arachis hypogea L.) to drought stress and its amelioration: a critical review, Plant growth regulation.41, 75-88. https://doi.org/10.1023/A:1027353430164

Revoredo, C. L., \& Fletcher, S. (2002). "World peanut market: an overview of the past 30 years," Georgia Agricultural Experiment Stations, College of Agricultural and Environmental Sciences, the University of Georgia.

Sarr, B., Ndiendole, S., Diouf, O., Diouf, M., \& Roy-Macauley, H. (1999). Suivi de l'état hydrique du sol et de la température du couvert du maïs (Zea mays L.) au Sénégal. Sécheresse 199910 (2), 129-135.

Singh, P., Nedumaran, S., Ntare, B., Boote, K., Singh, N., Srinivas, K., \& Bantilan, M. (2013). Potential benefits of drought and heat tolerance in groundnut for adaptation to climate change in India and West Africa. Mitigation and Adaptation Strategies for Global Change.

Stirling, C., Black, C., \& Ong, C. (1989). The Response of Groundnut (Arachis hypogaea L.) to Timing of Irrigation II. 14C-PARTITIONING AND PLANT WATER STATUS. Journal of experimental botany 40, 1363-1373. https://doi.org/10.1093/jxb/40.12.1363

Team, R. (2014). RStudio: integrated development for R. RStudio, Inc., Boston, MA. URL http://www. RStudio. com/ide.

Vaghasia, P. M., Jadav, K. V., Jivani, L. L., \& Kachhadiya, V. H. (2010). Impact of water stress at different growth phases of summer groundnut (Arachis hypogaea L.) on growth and yield. 693-696.

Vurayai, R., Emongor, V., \& Moseki, B. (2011). Effect of water stress imposed at different growth and development stages on morphological traits and yield of Bambara Groundnuts (Vigna subterranea L. Verdc). American journal of plant physiology 6, 17-27. https://doi.org/10.3923/ajpp.2011.17.27

Webb, N., Nichol, C., Wood, J., \& Potter, E. (2008). User Manual for the SunScan Canopy Analysis System,(2.0 Version). Delta-T Devices Ltd.: Cambridge, UK, 83.

Wright, G., Hubick, K., \& Farquhar, G. (1991). Physiological analysis of peanut cultivar response to timing and duration of drought stress. Crop and Pasture Science 42, 453-470. https://doi.org/10.1071/AR9910453

Wright, G., \& Rao, R. N. (1994). Groundnut water relations. In "The Groundnut Crop", pp. 281-335. Springer. https://doi.org/10.1007/978-94-011-0733-4_9

Yao, J. P., Luo, Y. N., \& Yang, X. D. (1982). Preliminary report on the effect of drought and seed development and quality of early groundnut. Chinese Oil Scops 3, 50-52.

\section{Copyrights}

Copyright for this article is retained by the author(s), with first publication rights granted to the journal.

This is an open-access article distributed under the terms and conditions of the Creative Commons Attribution license (http://creativecommons.org/licenses/by/4.0/). 